\title{
Midwives are Ready to Provide the Best Quality Service for the Society
}

\author{
Jenny J. S. Shondakh ${ }^{1}$, Naimah ${ }^{2}$ \\ State Health Polytechnic of Malang, Ijen Boulevard 77C Malang
}

\begin{abstract}
The Midwives Self-Service Practices such as Maternal and Infant Health (KIA) Program performed by midwives as one of the top priorities for health development in Indonesia. This is one of the efforts that has a relatively rapid impact for decreasing Maternal Mortality Rate and Infant Mortality Rate. Considering it, Indonesian Midwives Association (IBI) launch The Midwives SelfService Practices program to be recruited as Bidan Delima. The predicate of Bidan Delima give for Midwives Self-Service Practices who have been qualified as Bidan Delima. The purpose of this research is to analyze the relation between Bidan Delima services and Social Security Administrator (BPJS) Customer Satisfaction in receiving service from Bidan Delima and also as motivation for another Midwives Self-Service Practices for joining Bidan Delima. The design of the research is correlation analysis with crosssectional approach. The research population is whole pregnant mother, delivering mother, Family Planning (KB) acceptor, postpartum mother, and the customers who checked their infants at Midwives Self-Service Practices at Batu City at June 2016. The sample of this research were 119 people, who taken with Stratified Random Sampling technique. The variable of this research is Bidan Delima services and BPJS customer satisfaction. The data collected with questionary, and analyzed with Fisher Exact Test. The result is $p=0,016$ on $\alpha=0,05$ obtained H1 received, it means there is a relationship between Bidan Delima services with BPJS customer satisfaction at " $W$ " Midwives Self-Service Practices at Batu City.
\end{abstract}

Keywords: Service, BPJS Satisfaction

\section{Introduction}

Midwives as one of profession in health field, besides authorized for provide family planning and public health, especially mother and child.

In Indonesia the highest rate of maternal and infant health, at 2007 for AKI (Maternal Mortality Rate) as 228/100.000 live births, while for AKB (Infant Mortality Rate) at 2007 as 34/1000 live births. ${ }^{[1]}$

One effort that has a relatively rapid impact to decreasing $\mathrm{AKI}$ and $\mathrm{AKB}$ is providing a certain quality of midwives which is close to the community, and supported by increasing range and quality of referral services. One of Indonesian Midwives Association (IBI) effort is the cooperation with National Population and Family Planning Agency of Indonesia (BKKBN) and Health Department, and also a technical support from USAID (United States Agency for International Development) through STARH Sustaining Technical Assistance in Reproductive Health) program, and HSP (Health Service Program) year 2005-2009 developing Bidan Delima programs, for developing service quality of Midwives Self-Service Practices and providing a reward for them who had achievement in service of Family Planning and Reproduction Health. Bidan Delima is midwife that provide certain quality, which clients should be satisfied with that given services. ${ }^{[2]}$

Measurement of clien satisfaction is absolutely necessary, for improving the quality of health services. with that measurement, it can be known how far the dimensions of health service quality can meet patient expectation. The success of a health service in improving the quality of health service very closely related to client satisfaction, so that the client feels comfortable and feel the satisfaction in a person. [3]

Social Security Administrator (BPJS) is one of the national standard social security programs. One of them is Social Security Administrator of Health (BPJS Kesehatan) where midwifes, mainly Bidan Delima take a participation in government programs for maternal and infant health. ${ }^{[4]}$

Based on preliminary studies conducted, obtained data about health service range, especially in Bidan Delima BPM "W" at Batu City, in 1 month for ANC 24 of 97 pregnant mother (25\%), INC 20 of 84 delivered mother (64\%), KB 67 of 174 PUS who become KB acceptor (39\%), immunization 25 of 67 infant under 1 year old (37\%) and PNC 17 of 84 postpartum mother $(20 \%)$ and health service on toddler 27 of 107 toddler count $(25 \%)$. From the data it can be know that the coverage of health services has not reached half of the total. Unsatisfaction can be occur because there is a gap between expectations and the performance of health services. [4]

Based on the above description the author interested for researching about the relation between Bidan Delima services and BPJS customer satisfaction at BPM "W" in Batu City.

\section{Research Method}

This research using correlation analysis with cross sectional approach. In this case analyzing the relation between Bidan Delima services and BPJS customer satisfaction. Where BPJS customer which meet the inclusion criteria of 119 people consisting of pregnant mother (16 people), delivered mother (13 people), KB acceptor (44 people), postpartum 


\section{International Journal of Science and Research (IJSR) \\ ISSN (Online): 2319-7064 \\ Index Copernicus Value (2015): 78.96 | Impact Factor (2015): 6.391}

mother (11 people), client who immunized their infant (17 people), client who check their infant health (18 people).

Assessment of type data of Bidan Delima services and data of BPJS customer satisfaction using questionnaires. Then, the level of BPJS customer satisfaction is do with identification using Likert scale. Obtained data will be processed with Coding, Scoring, Transferring, and Tabulating. Then the data is tested with Fisher Exact.

\section{Result}

Frequency Distribution of Costumer satisfaction Category in receiving Bidan Delima services.

Table 1: Table of Frequency Distribution of Costumer satisfaction Category in receiving Bidan Delima services at BPM "W" in Batu City on 2016

\begin{tabular}{|c|c|c|}
\hline Category & Frequency & Percentage (\%) \\
\hline Satisfied & 92 & 77,31 \\
Unsatisfied & 27 & 22,69 \\
\hline Total & 119 & 100 \\
\hline
\end{tabular}

According from the data above, it can be seen that for the satisfied category percentage is greater $(77,31 \%)$.

Table 2: Table of Cross Relation of Bidan Delima Services with BPJS Customer Satisfaction at BPM "W" in Batu City on 2016

\begin{tabular}{|c|c|c|c|c|c|c|}
\hline Satisfaction & \multicolumn{2}{|c|}{ Satisfied } & \multicolumn{2}{c|}{ Unsatisfied } & \multicolumn{2}{c|}{ Total } \\
\hline KIA Services & Freq. & $\%$ & Freq. & $\%$ & Freq. & $\%$ \\
\hline ANC & 10 & 10,87 & 6 & 22,22 & 16 & 33,09 \\
\hline INC & 11 & 11,96 & 2 & 7,41 & 13 & 19,37 \\
\hline PNC & 9 & 9,78 & 2 & 7,41 & 11 & 17,19 \\
\hline KB & 35 & 38,04 & 9 & 33,33 & 44 & 71,37 \\
\hline Immunization & 15 & 16,30 & 2 & 7,41 & 17 & 23,71 \\
\hline $\begin{array}{c}\text { Toddler } \\
\text { Health } \\
\text { Services }\end{array}$ & 12 & 13,04 & 6 & 22,22 & 18 & 66,66 \\
\hline Total & 92 & 100 & 27 & 100 & 119 & 100 \\
\hline
\end{tabular}

Table 2 showed the greatest number of satisfied category is KB services $(38,04 \%)$ and the smallest is PNC $(9,78 \%)$. Then, the greatest number of unsatisfied category is also KB services $(33,33 \%)$ and the smallest is INC, PNC, and Immunization, respectively $7,41 \%$

Result of hypothesis test in this research done with using Fisher Exact. Result of Fisher Exact, which is manually done and using SPSS software. After researching with Fisher Exact formula obtained from the result of Fisher Exact statistic test score $\mathrm{p}=0,016$ on $\alpha 0,05$, it means $\mathrm{p}<\alpha$ then $\mathrm{H}_{1}$ accepted. It means there's a correlation of Bidan Delima Services with BPJS Customer Satisfaction at BPM "W" in Batu City on 2016

\section{Discussion}

From the research result obtained there's a relation Bidan Delima Services with BPJS Customer Satisfaction at BPM "W" in Batu City. BPJS Customer feel satisfied with the services by Bidan Delima. The Satisfied Category at most on Family Planning (KB) service.
This is consistent with that presented by central committee of IBI, that Bidan Delima is midwife who give certain quality, best service and reachable so that client satisfaction both individually, family and society can be achieved where Bidan Delima developed for give an award for Self Service Midwives Practice who get achievement in KB services and reproduction health. But of course not just KB service which is favored, but KIA service and the others also expected to be good quality, so that meet the client expectation, that is better state that before, after get medical service ${ }^{[2]}$

Cannot be ignored that everyone's assessment of quality from the health service is different. There is two factors that affect the service quality, that is: Expected Service and Perceived Service. While customer expectations in receiving services can be affected by several factors, there is: What is heard by customer from another customer which is usually called from mouth to mouth service, The desire of each individual that depends on the characteristics and circumstances faced by the customer, Customer experiences for using past service, communication from the outside that is related with providing of health services.

Besides of several factors above there is another several factors that affect services quality that affect client Satisfaction, such as: facilities, health workers, funds, process element in the form of medical and non medical action and the way of midwives welcomed the client such as, Friendliness, smile and accuracy in answering questions, or responding to client complaints also affect client's feelings. Even more important is the situation where the client feels their privacy or secrecy is maintained and midwifes give a chance for the client to tell about their problem or complaints [3]

That above can make a client's judgment about Bidan Delima service said good quality.

\section{Conclusions and Suggestions}

There is a relation between Bidan Delima Services with BPJS Customer Satisfaction at BPM "W" in Batu City. Can be concluded that midwives are ready to provide the best quality service for the society.

\section{References}

[1] Departemen Kesehatan. 2003. Pedoman Pemantauan Wilayah Setempat Kesehatan Ibu dan Anak. Jakarta: Depkes

[2] Pengurus Pusat Ikatan Bidan Indonesia. 2008. Buku Instrumen Bidan Delima (1,2,3,4). Jakarta: IBI

[3] Supranto, J. (2006). Pengukuran Tingkat Kepuasan Pelanggan. Jakarta: PT Rineka Cipta

[4] Pohan. 2006. Jaminan Mutu Layanan Kesehatan.Jakarta: EGC

[5] Savitri R. 2004. Tingkatan dalam kecemasan. Bandung : CV. Alfabeta 
Author Profile

Jenny J.S. Sondakh, Graduated with a Bachelor of Midwife at State Health Polytechnic of Malang in 2003. Graduated Master of Clinical Midwifery at Melbourne University Australia in 2009. Now a lecturer at the Health Polytechnic of the Ministry of Health of Malang, Field of Science which is occupied is Midwifery.

Volume 6 Issue 7, July 2017 www.ijsr.net 